\title{
A Tower to Console the Dead and the Living: Masumi Hayashi and the Image of History
}

\author{
Jason Francisco \\ Emory University, Atlanta, GA, USA \\ jlfrancisco@earthlink.net
}

\begin{abstract}
This article critically investigates the work of the Japanese American photographer Masumi Hayashi $\left(1945^{-2006)}\right.$, with special attention to her series on World War II era internment camps for people of Japanese ancestry. It has three goals: to describe Hayashi's unusual working method through close attention to the works themselves; to articulate the aesthetic, philosophical and ethical dimensions of Hayashi's practice; and to position Hayashi within the field of late twentieth-century and early twenty-first century photographers concerned with the problem of giving-image to traumatic histories. The author argues for recognition of Hayashi's deeply accomplished, ground-breaking work.
\end{abstract}

\section{Keywords}

Japanese internment - Masumi Hayashi - photography - chronopanorama - trauma memory - women photographers

There is a delicate form of the empirical which identifies itself so intimately with its object that it thereby becomes theory.

- JOHANN WOLFGANG VON GOETHE ${ }^{1}$

1 Johann Wolfgang von Goethe, quoted by Walter Benjamin in "Little History of Photography," Walter Benjamin: Selected Writings, Volume 2, Part 2, 1931-1934, ed. Michael W. Jennings, Howard Eiland, and Gary Smith (Cambridge, MA: Belknap Press, 2005), 5. 
For a long time, behind my own artistic practice, I have wrestled with problems in aesthetics, especially the philosophical distinctions between writing, telling, visualizing, and imagining. It has never been very clear to me, for example, just what the difference is between showing things and telling them. It seems to me almost self-evident that language is a catalytic element of what pictures come to mean: the informational, narrative, and metaphoric ways we speak about pictures become the very fibre of what they show us. And it seems to me, conversely, that speaking is in and of itself an exercise in showing: words continuously represent-manifest, designate, gesture toward — that which exists outside of language, and grammar itself points constantly to its own usage, to a demonstration that underwrites explanation. Likewise, it seems to me that there is a strong interdependence between a picture of something and a proposition about it. All manner of images, from graphic designs to mirrors to dreams and memories, naturally exhibit a radical inconstancy of meaning that leans on speech for stability, just as speech similarly relies on images-on visual and other types of sensory apprehension-for interpretive ballast, without which even the objective contours of reference struggle to appear.

I encounter these kinds of philosophical problems without being a philosopher, which I liken to finding myself on a boat in the middle of an ocean without any skill at sailing. Rather I am a photographer, the kind for whom theoretical complications run underneath everything else, sometimes breaking the surface and emerging into sentences-itself a mysterious experience that is also a reason to be wrestling. I am wrestling because I am not thinking about these problems in the abstract, but specifically as preamble to the legacy of Masumi Hayashi, an artist whose work I have been pondering for more than twenty years. Masumi Hayashi: a kindred soul of a photographer, who spent her creative life figuring out a synthetic practice of writing-telling-visualizingimagining, using photographs to address a primary concern with traumatic history, to shape grief into a turbulent clarity, enough to give image to rupture and loss, as these are encoded both within memory and the physical sites of memory themselves.

It escapes me just how Masumi Hayashi came to artistic maturity. I can neither reconstruct her artistic education, nor recover the words she used to describe her own artistic self-understanding. ${ }^{2}$ It is clear, though, that by the time she

2 Hayashi's decade-old memorial website, www.masumimuseum.com, still the best source of information about her work, contains very little of her writing. The closest thing to an 
arrived in Cleveland in 1984 to begin her teaching career at Cleveland State University - twenty-two years prior to her untimely death in 2006-she was already committed to the panoramic tradition, and already adept at a new, aesthetically sophisticated handling of it. ${ }^{3} \mathrm{Or}$, more precisely, she was skilled at a type of visual deconstruction of a photographic idiom that has always been pictorially provocative, even in conventionalized forms. ${ }^{4}$ For Hayashi, the panoramic tradition offered a potent entry point into what I would call photography's predicating paradoxes, a keen understanding of which she managed to infuse into all of her mature works, and in particular her series on Japanese Americans prison camps during World War II.

I imagine the formative years of Hayashi's artistic life this way: through a series of accidents and productive missteps, she discovered that the panoramic idiom induces a form of visual thinking suited to the artistic tasks she came to understand she carried within herself. Specifically, those tasks centred on the urge to give image not only to that which stands to be seen, but precisely to that which resists being seen - the unhealed wounds of history. I can almost see her inventing her distinctly daedal form of panoramic work, which is capable

account of her internal process comes in a short statement she wrote in 1992 about her EPA Superfund work: "How one becomes interested in a project is a curious process. I find that the themes for my panoramic photo collages have evolved in many ways, and seem to reflect my social and historical consciousness, my own background and anxieties..." See http://masumimuseum.com/index.php/about/statement (accessed 13 July 2017).

3 Hayashi was born in the prison camp for Japanese Americans at Gila River, Arizona on 3 September 1945 and was murdered on 17 August 2006 in Cleveland, Ohio by a deranged neighbour in the building where she kept her studio.

4 The word "panorama" predates the 1839 announcement of photography by half a century. It was coined around 1792 by the English painter Robert Barker to describe his paintings of Edinburgh presented on a cylindrical surface as an unbroken picture in the round-an image overly Excessivist, incapable of being completely seen from any single vantage point, and thereby forcing the act of seeing into the precisely embodied experience of "looking around." In this originary form, the panorama could be read either as unending and all-inclusive, or the reverse, as self-enclosing and self-limited-a similar conceptual contest that Hayashi learned to restage in her treatment of the panoramic idiom, as I will show below. Unlike painted versions, photographic panoramas were almost always made for flat presentation, either by piecing together discrete pictures made using commonly available cameras, or-by the end of the nineteenth century - by using special spring-turned cameras to create long, wide negatives. In photography, the panorama came to connote the kind of all-seeing, allcomprehending view that had been equivocal in its early forms, but with a decidedly unusual visual language, inasmuch as a flattened rendition of a $360^{\circ}$ view has the optical effect of simultaneously compressing space and splaying it open, so that the cardinal directions all sit side by side and perpendicular lines appear as a set of linked chevrons, or sometimes a scalloping chain. 
of drawing the surfaces of the visible world into a dialectic of information, symbol, and myth. Fundamentally, Hayashi learned to treat pictures as testing spaces, in which three aspects of photographic images-or more strongly, three powers of photography, three sides of its unique cultural agency-are entered into ontological tension. First, in the manner of a documentarian, she wanted a picture to transport us outside of the picture itself, that we would encounter a world we imagine to exist independent of the act of representation. Second, in the manner of a conceptual artist, she wanted that we would reckon with a skilled handling — and sometimes mishandling—of that world, which we credit to the artist as maker, designer, and sometimes director. Third, in the manner of a scientist (or, perhaps, a shaman), she wanted that we would encounter an investigative process at work and at play, a process of discovery acting on the world and on the artist, moving with its own momentum and reason for being.

It is worth describing in detail how Hayashi's panoramic technique both elaborates and explodes the panoramic tradition. All of her panoramas are built of 8 o to 120 colour prints, generally 4 inches $\times 6$ inches $(10.2 \mathrm{~cm} \times 15.2 \mathrm{~cm})$, which are pieced together as a grid. Each photograph functions as a patch, tile, or tessera, and the finished works strongly recall quilts, puzzles, and mosaics. They are correctly called collages- though without the freeform connotations that word tends to carry — or perhaps assemblages, of a distinctly flat sort. Perhaps, to coin a word, they can be called "opticopias," for reasons I will explain. To make her pictures Hayashi used a $35 \mathrm{~mm}$ camera mounted to a tripod, most likely fitted with a $100 \mathrm{~mm}$ or $120 \mathrm{~mm}$ lens. ${ }^{5}$ She studied the globe of space surrounding her, divided it into tiers, and then photographed each tier from a fixed vantage point, rotating the camera a predetermined amount for each image. When she finished one tier, she moved to the next. "Finishing" one tier did not mean photographing it only once: on the contrary, she would photograph each tier multiple times, thereby elaborating the second key variable in her process. It is impossible to say how much time it took her to make each contributing picture, but it is clear that each tile represents a distinct temporal statement, a distinct moment in a collection of moments. By photographing each tier more than once, Hayashi allows these differences to accrete. The result is not just a panorama but also a chronorama - a sweeping, omnipercipient, ingathering view of time. The slight differences between one photo-tile and the next form a subtle description in the idiom of stillness (completely different from what a

5 Since Hayashi typically used seventeen to nineteen photographs to describe a $360^{\circ}$ view, each piece shows an approximate $18^{\circ}-20^{\circ}$ range, which generally corresponds to the field of view given by a $100 \mathrm{~mm}$ or a $120 \mathrm{~mm}$ lens. 
time-based image would look like) of how places exist in continuous states of change. Or, to smash these two terms together, Hayashi worked in a form that should be called "panochronoramic": a view of space ranging from $360^{\circ}$ to as much as $450^{\circ}$ horizontally, and $60^{\circ}$ to $80^{\circ}$ vertically, showing a constellation of moments whose production compassed hours, and whose emotional expression compassed decades and generations.

Hayashi's 1992 work on the Manzanar site in California's Owens Valley (fig. 1 ) shows us an approximately $400^{\circ}$ view of the entrance to the former prison camp, a view "through" (what the image presents as) a pair of gates, which is in fact a single gate doubled. The direction immediately to the left of the right-side gate is west - the direction toward which the shadow of Hayashi's tripod points, confirming that she made this picture in the early morning, as the sun was rising in the east. To put the picture into historical dialogue, Hayashi's tripod arrow points in precisely the same direction as Dorothea Lange's 1942 picture of a dust storm in the Manzanar camp (fig. 2). Looking at the two photographs together, it is difficult not to connect the lines of Hayashi's tripod-standing in, I suppose, for Hayashi's own figure, her own conscience as a witness - with the lines of Lange's flagpole and telephone poles. In Lange's picture, the American flag appears as a symbol of unfreedom and deep hypocrisy. ${ }^{6}$ It snaps violently in the wind, presiding with ignominy over an American

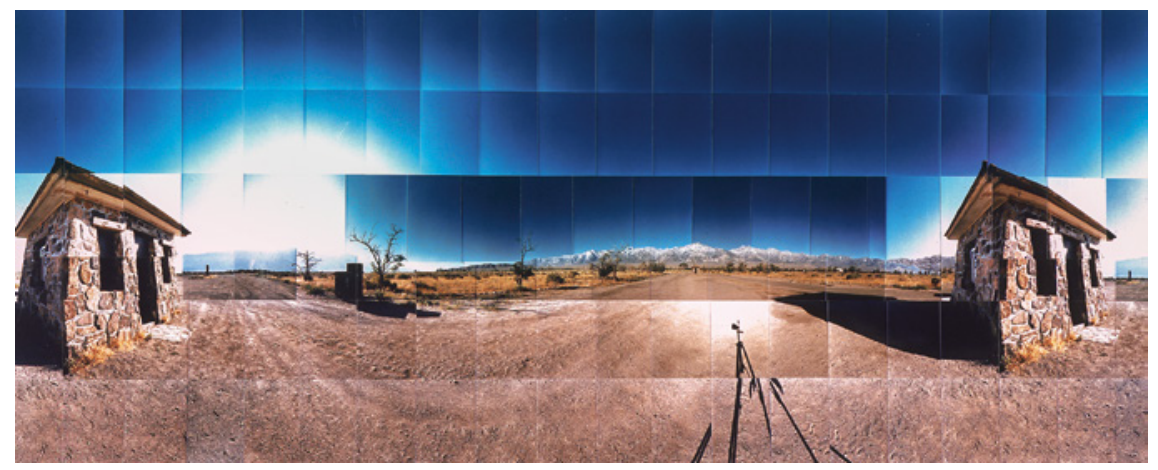

FIGURE 1 Masumi Hayashi, Manzanar Relocation Camp, Guard Gates, Inyo, California, 1992, panoramic photo collage with Fuji Crystal Archive prints, 27 inches $\times 65$ inches. (C) MASUMI HAYASHI.

6 The order authorized the Secretary of War to prescribe certain areas as military zones, leading to the comprehensive detainment and deportation of approximately 120,000 people of Japanese ancestry-approximately 70,000 of whom were us citizens-into armed prison camps in isolated, barren locations. The camps were closed by the end of 1945. Approximately 11,000 people of German ancestry were also imprisoned (including German Jews), 


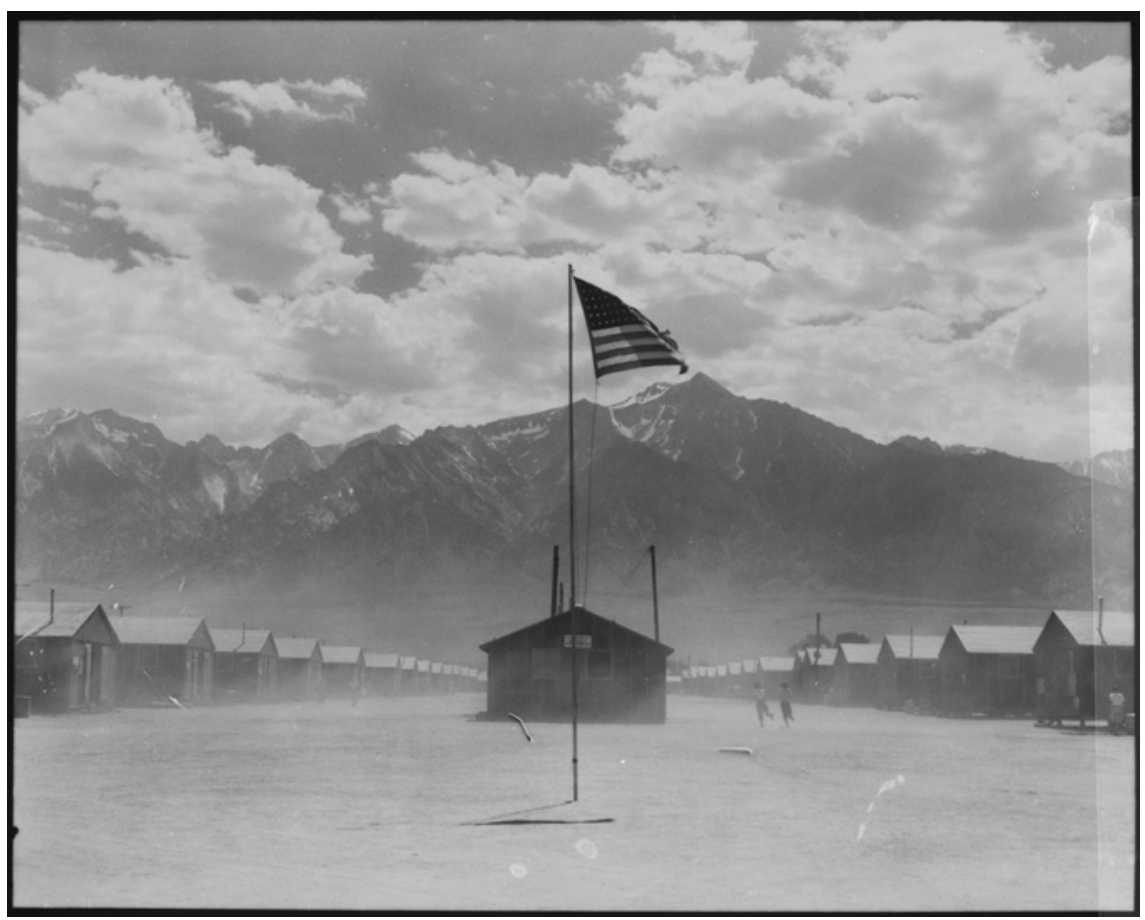

FIGURE 2 Dorothea Lange, Manzanar, California (original caption subtitle: "Dust storm at this War Relocation Authority center where evacuees of Japanese ancestry are spending the duration"), July 3, 1942. Photographed by Dorothea Lange for the War Relocation Authority. Image provided by the National Archives and Records Administration (NARA), Washington, DC, USA (archives identifier 539961, local identifier 210-GC-839).

prison camp established explicitly through a legalized program of ethnic profiling. It is one camp in a network of camps intended for the indefinite detention

and some 3,000 people of Italian ancestry. Transit camps were established in California at Arcadia, Fresno, Marysville, Merced, the Owens Valley, Pinedale, Pomona, Sacramento, Salinas, San Bruno, Stockton, Tulare, Turlock, and Woodland; in Arizona at Mayer and Parker Dam; in Portland, Oregon; in Puyallup, Washington; in Texas at Crystal City, Kennedy, and Seagoville; in New Mexico at Fort Stanton and Santa Fe; in Kooskia, Idaho; in Fort Lincoln, North Dakota; in Fort Missoula, Montana; and in Forest Park, Georgia. The ten permanent camps were Manzanar and Tule Lake in California, Gila River and Poston in Arizona, Heart Mountain in Wyoming, Granada in Colorado, Jeroma and Rohwer in Arkansas, and Topaz in Utah. Additionally, detainees were also held at three special "Citizen Isolation Centers," three federal prisons, and eighteen military bases across the United States. The Civil Liberties Act of 1988 granted reparations to 82,219 Japanese Americans interned during World War II. The legislation stated that the us government acted based on "race prejudice, war hysteria, and a failure of political leadership." 
of people branded potential enemies of the American state-at the very time the us was fighting to liberate Europe from the hold of fascism. ${ }^{7}$

Like all of Hayashi's panochronoramas, the 1992 Manzanar piece is overtly self-contradictory: the view is at the same time discontinuous and continuous, self-dispersive and self-integrative, ruptured and repaired. Its intactness is equally provisional and intricate, existing by means of - and not in spite of - a play of visual contingencies. While the image is replete with sheer visual effect, or what the artist Martha Rosler calls "aesthetic surplus" (for example, the variegated palette of blues that describe the sky, typical of the abrash effect Hayashi often created in areas that would appear as solid colour in a straight photograph), this is not a case of "an antically unrecognizable political dimension," again to use Rosler's words. ${ }^{8}$ On the contrary, Hayashi's method is politically driven in at least two senses. First, the 1992 Manzanar piece is part of a comprehensive visual reckoning with all ten permanent Japanese American prison camps that the us government established, as well as several Canadian government-sanctioned camps established for the same purpose. The 1992 Manzanar piece sits at the front end of this project, which Hayashi began in 1990 and then pursued in earnest between 1992 and 1997. Her work on the camps is in turn nested within several other sustained series on traumatized American spaces: post-industrial landscapes (1986-1992), E PA Superfund sites (1990-1992), abandoned prisons (1993-1996), and war and military sites (1990-1999). ${ }^{9}$ Further, for the Japanese American prison camps (and only for this series), her work went beyond photographing the sites themselves. She

7 The American prison camps and the policies that created them existed in profound violation of civil and human rights, caused deep psychic wounds and resulted in great material losses for victims, but it is worth noting that the American camps were not genocidal in intention or in effect, in contrast, for example, to German camps established for European Jews during World War II.

8 See Tim Griffin, "Global Tendencies: Globalism and the Large-Scale Exhibition," Artforum 42, no. 3 (November 2003): 152-163 (transcription of panel moderated by James Meyer, with panellists Francesco Bonami, Catherine David, Okwui Enwezor, Hans-Ulrich Obrist, Martha Rosler, and Yinka Shonibare).

9 Hayashi's work on war and military sites does not focus exclusively on the us context, but extends to genocidal sites in Germany and Cambodia, specifically the Nazi camps at Ravensbrück and Sachsenhausen, and the Khmer Rouge killing fields in Phnom Penh. It is also important to note that her international work was mostly not devoted to sites of historical trauma, rather the reverse - to sites of sacred architecture in India, Nepal, Japan, Thailand, and Cambodia. Her complete oeuvre thus lays out a vision from agonized to lenitive and perhaps redemptive. A deep account of her practice — something she badly deserves and something I hope will emerge in coming years as scholars and historians rediscover her-should wrestle with precisely this duality. And it should wrestle with something else: since all of works in the last twenty years of her life are made using this collage/recombinative technique, including 
also made a series of portraits of survivors in the collage/recombinative form (although in a somewhat different variation) and conducted extensive interviews with them. Her audio recordings run to dozens of hours. The camp photographs, the portraits, and the audio recordings together form an explicitly political commitment, one that sits at the very heart of her oeuvre even if she never fully pulled these related projects into a single omnibus statement on the camps before she died.

Second, Hayashi's art is immanently political in her effort to innovate a type of photographic image conceptually equal to the challenges of fractured historical consciousness in late twentieth-century America. Hayashi's pictures are intrinsically dialectical, simultaneously self-seeking and self-disputing. In each case we see a paradoxically broken whole, made of cuts and sutures, the incisions not healed, each internal edge still sharply delineated, not yet grown over with whatever kind of invisible scar tissue would render the scene a seamless whole. Indeed, the images seem midway between madness and peace. They seem as close to an entirely different visual solution-in which the pieces are joined anarchically without even attempting a coherent view - as they do to a blended whole giving an (artificial) sense of control or cognitive mastery over the place. Further, it is not by accident that the structuring logic of all of Hayashi's other site-based works is the grid-no accident that straight lines and right angles form a kind of substrate, or deep architecture from which her vision takes shape. The grid is, of course, a key emblem of modernity, and specifically oppressive modernity — of endlessly self-replicating character of impersonal and systematic power. In choosing the grid, Hayashi does not choose, for example, to cut the photographs freehand and piece them together as organic shapes (something she could certainly have done). In claiming the grid, Hayashi embeds her vision in the iconic terms of the ordered, disciplined, and autotelic power of the state and indeed the cultural consciousness responsible for the camps. ${ }^{10}$ On the other hand, in choosing to work from the grid, Hayashi chooses also to work with it, to subvert and reorient its meanings such that it becomes for her, as for other postmodern artists, also an instrument of extended (critical) seeing, something of a ludic device, and even a liberatory symbol of infinity and release.

commissions and commercial works, it is fair to ask counterfactually: What kind of work would she have deemed not appropriate for this method?

10 See Rosalind Krauss' essay "Grids," October 9 (Summer 1979): 50-64, for a canonical account of the formative role of the grid in the development of modern art after World War I. At midcentury, the grid was the key link between Minimalism and Conceptualism, especially the turn toward dematerialization of the art object. 
In this connection, it is well to look carefully at how Hayashi actually makes her pieces, and to notice the ways they are the product of her eye and her hand equally. ${ }^{11}$ For Hayashi, to see is to see generatively, to produce rather than to reproduce, to show the world in a condition of being seen rather than as an inert object of sight. In this sense her approach is relational, grounded in an intuitive understanding of the connections between (artistic) responsiveness and (social and historical) responsibility. For Hayashi, to respond is to become responsible, and to be responsible entails actually responding. ${ }^{12}$ Thus in the 1992 Manzanar piece, the guardhouse appears in two different forms, its windows and doors and walls differently shaped, its roofline differently contoured, as if to state that it is not one thing, not entirely reconciled to itself and not merely itself, and that the act of apprehending it is neither static nor transcriptive in its character. The guardhouse on the right side appears in detail in Figure 3. Here it is clear that Hayashi's approach to the grid is variegated: the photo-tiles are not the same size, and the edges of the pieces are not uniformly aligned. The same 1992 Manzanar piece contains a number of interventions done by hand, most obviously in the appearance of the mountain range on the western side of the former camp site. As the detail in Figure 4 shows, Hayashi layered the photo-tiles showing these mountains, and carefully incised them to follow the mountains' contours. The thickness of the photographic paper contributes a white outline that brings the tops of the mountains forward optically, lending them emphasis. Careful study of this piece also reveals that the stony ground along the lower edge of the piece is quite inventively described. The bottommost row of pictures shows a distinctly flat, rather than subtly receding, space-Hayashi used pictures that looked straight down at the ground-and actually reuses the same photo-tiles in different places.

11 I first learned of Hayashi in 1997, but had never seen her work in person until 2016. As always, there is no substitute for seeing an artist's work first-hand, and for this opportunity I wish to thank Hayashi's son Dean Keesey, and Michael Gentile, who pulled several of Hayashi's pieces from deep storage for me to study. I also wish to thank others in Cleveland who knew and loved Hayashi, and were generous in helping me in my research: Bruce Edwards, Piet van Lier, Linda Butler, and Barbara Tannenbaum.

12 The question of whether Hayashi's works amount to a phenomenology of seeing is complex. On the one hand, her works do externalize an empirical experience of seeing, especially in the ways their staccato qualities directly reproduce the stepped processes of their making. On the other hand, the works are highly stylized and indeed systematized, and as such follow from a concerted strategy for producing acts of seeing, one capable of endowing acts of seeing with historical reach—a strategy that is autonomous and selfvalidating, apart from specific locations and experiences in which it is enacted. 

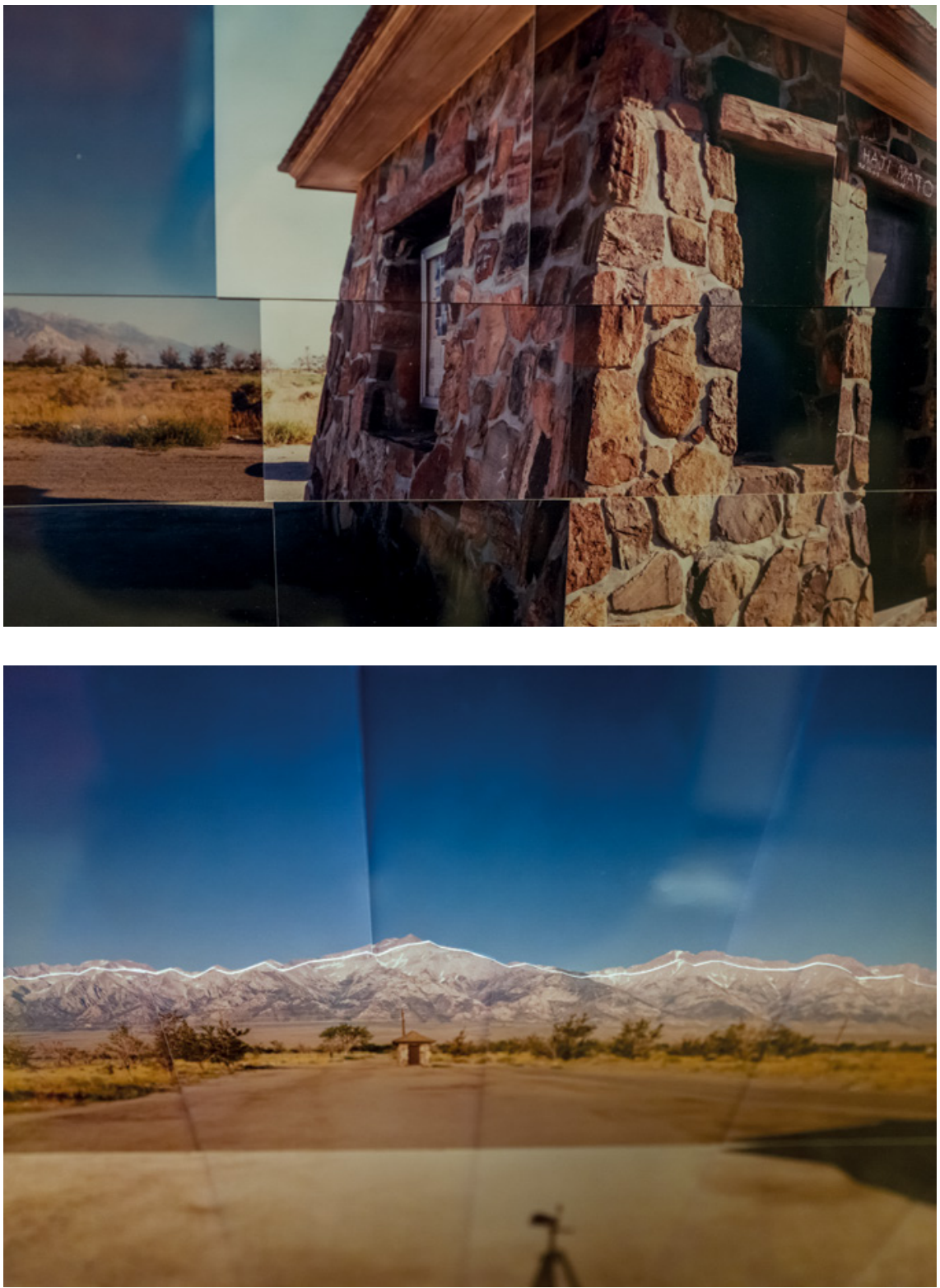

FIGURES 3-4 Masumi Hayashi, Manzanar Relocation Camp, Guard Gates, Inyo, California, 1992 (detail), panoramic photo collage with Fuji Crystal Archive prints, 27 inches $\times$ 65 inches.

(c) MASUMI HAYASHI. DETAIL PROVIDED BY JASON FRANCISCO. 
Likewise, in her 1995 piece Manzanar Relocation Camp, Monument (Version 1), Inyo, California (figs. 5-6), the obelisk in the Manzanar cemetery appears as other than a solid piece of concrete. Seven photo-tiles comprise Hayashi's description of the monument, varying in size, tint, and exposure. Its inscription, 慰霊塔 ( $i$ rei tõ), literally meaning "spirit-comfort-tower"-or phrasally perhaps, "tower to console the souls of the dead and the living" - appears as the topmost block on a ziggurat, as much leaning as it is erect, perched on a structure that seems constitutively under construction, as if built and rebuilt by those consolation-seeking souls. Like the pebbly ground of the 1992 Manzanar piece, the sky of the 1995 piece is inventive and even fanciful, the top row in certain ways disconnected and free-floating, especially along the left side. Like the rebuilt guard gate of the 1992 piece, the cracked concrete rectangle in front of the obelisk is rendered in the shape of a fan, with spikes and sharp edges. The fan-like shape is a key motif in her interior works, both in the camps and in the temples, and her use of it is a good measure of her masterful handling of her technique: the repetition is used for the sake of visual flexion rather than dizziness or the effect of double vision. Hayashi's goal is to create an expanded awareness of place and a sense of protracted encounter. To stand before each of her pieces is to contend with the process of splicing understanding together. It is to look into a patchwork moment expertly pieced by a quilter of time.

To describe the driven and experimental nature of her life's work, her determination to turn toward rather than away from troubled earth, to split

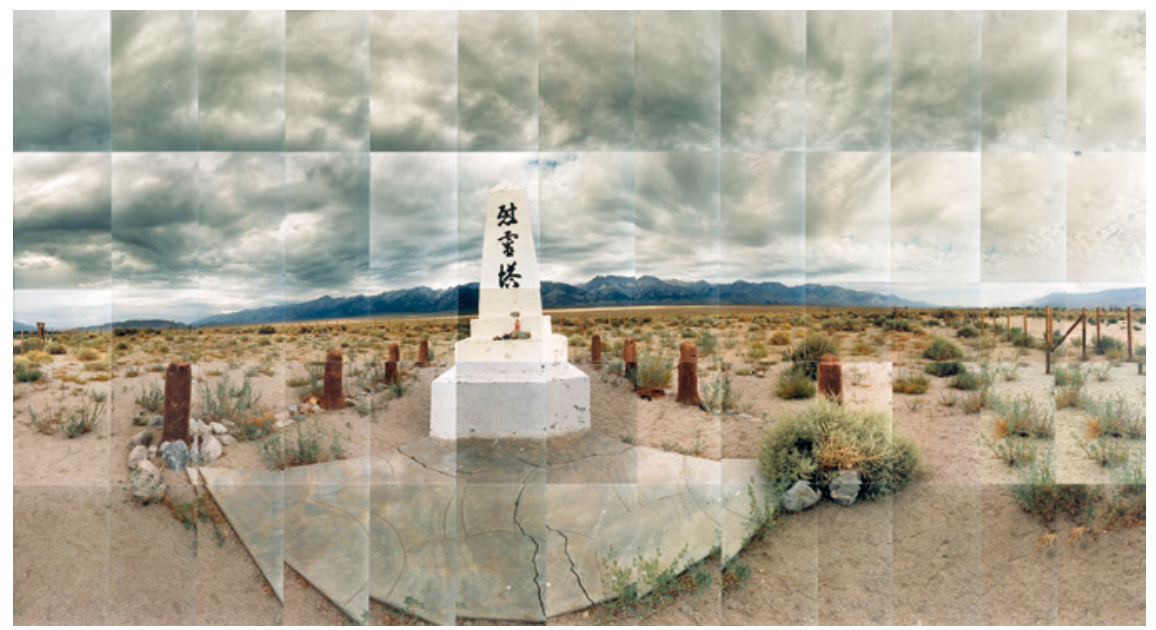

FIGURE 5 Masumi Hayashi, Manzanar Relocation Camp, Monument (Version 1), Inyo, California, 1995, panoramic photo collage with Fuji Crystal Archive prints, 20 inches $\times$ 30 inches.

(c) MASUMI HAYASHI. 


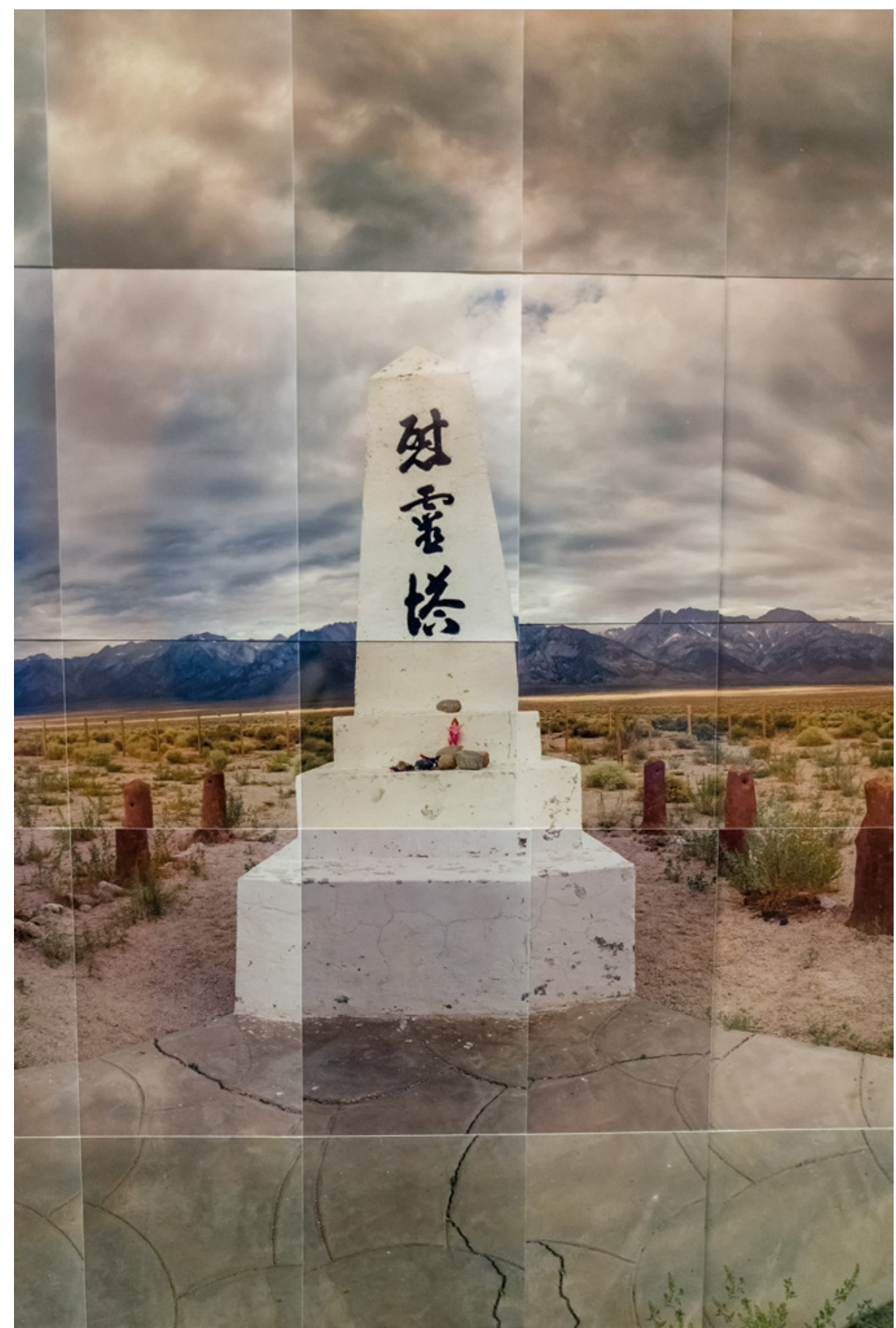

FIGURE 6 Masumi Hayashi, Manzanar Relocation Camp, Monument (Version 1), Inyo, California, 1995 (detail), panoramic photo collage with Fuji Crystal Archive prints, 20 inches $\times 30$ inches.

(c) MASUMI HAYASHI. DETAIL PROVIDED BY JASON FRANCISCO. 
open and refigure sites of suffering, to embroider them into new visions, and to sustain a penetrating ethical seriousness across her artistic investments, to explain these things about her it is possible to turn to labels-conceptualist, feminist, postmodern, dissident. ${ }^{13}$ To these labels I say: Is that the best we can do for her? To me these words are not so much unfair as they are limiting, and I am slow to want them.

It is better to say that Hayashi is an artist concerned with photography's frontiers - with those communicative tasks apart from the rhetoric of fact and disclosure, and apart also from issues of style and originality treated as cultic values that transcend (rather than mediate) social insight through photographs. Most accurately, she belongs to a loose group of late twentieth-century/ early twenty-first-century artists whose works in various ways direct the instability of the photographic image toward those varieties of social experience that are themselves unstable: social difference, loss, historical discontinuity, and the contradictions of power. In this group of artists I would include, for example (and in no particular order), Richard Misrach, An-My Lê, Binh Danh, Robert Polidori, Fazal Sheikh, Joel Sternfeld, Shai Kremer, Jessica Ingram, Andrew Moore, Oksana Yushko, Mikael Levin, Susan Meiselas, Juan Travnik, elin O'Hara slavick, Raphaël Dallaporta, Taryn Simon, Dana Lixenberg, Eric Gottesman, Claudia Heinermann, Wojciech Wilczyk, Jason Lazarus, Andrzej Kramarz, Christoph Schütz, Ahlam Shibli, Alfredo Jaar, Patrick Nagatani, and many of own my photoworks. ${ }^{14}$

I would go even further to argue that Hayashi's work contributes importantly to our understanding of the still under-theorized dimension of photographic meaning that I would call the ontology of absence. A thorough account of the ontology of absence is beyond the scope of this essay, but I can sketch its main aspects here. Photography's dominant tradition centres on what I would

13 There are valid connections to be made between Hayashi's works and, for example, Robert Smithson's concept of the Non-Site, Deborah Bright's political contestation of the Western American landscape, and Meridel Rubenstein and Ellen Zweig's Critical Mass, on the intersection of science and Native American worldviews at the time of the development of the nuclear bomb in the us.

14 See especially Nagatani's series Japanese-American C.C. on the Japanese American prison camps. Working contemporaneously with Hayashi, this is the only body of Nagatani's work that uses straight photography, compared to the collage technique for which he is well known. For a comparison of Hayashi and Nagatani's handling of the landscape of the Japanese American camps, see Jasmine Alinder, "Virtual Pilgrimage: The Contemporary Incarceration Photography of Patrick Nagatani and Masumi Hayashi," in Moving Images: Photography and the Japanese American Incarceration (Urbana and Chicago: University of Illinois Press, 2009). 
call the ontology of presence, which is the foundation of the commonsensical or vernacular understanding of photographic images. In the ontology of presence, photographs typically - prototypically — make what they show clear, evident, declared, present to us. So doing, by way of what I think of as a type of magical thinking specific to scientific societies, photography converts images into information understood to persist more or less apart from the image's stylization, qualities, and poetics. The photograph as informationalized image becomes, as a matter of its very being, an instrument of conservation. It is imbued with the power to capture, to hold captive, to store, to restore, to bear, and to transport times and places to other times and places, endowing the past with indeterminately prolonged visibility. Or to put it all differently, the ontology of presence is shorthand for the combined signifying powers of the world's claim on the camera-made image and the medium's capacity to create convincing likenesses. ${ }^{15}$ In the ontology of presence, aesthetic and philosophical realisms converge.

The ontology of absence begins from the counter-assertion that photographs do not make present what they show, do not make their referents clear and distinct, evident, and salient. As John Berger observed some decades ago, we should not mistake photography's capacity to preserve appearances with a capacity to preserve meaning. On the contrary, photographs "offer appearances - with all the credibility and gravity we normally lend to appearances-prised away from their meaning."16 To speak of the ontology of absence is to identify the abiding vagaries and misassurances of photographs, not toward a counter-faith in photographs' essential meaninglessness so much

15 In C.S. Peirce's famous scheme, signification occurs through three types of signs: the in$\operatorname{dex}$ (a sign with a physical relation to its referent, as a thumbprint), the icon (a sign that visually resembles its referent), and the symbol (a sign whose relationship to its referent is arbitrary even if conventionalized, as a flag represents a nation). See C.S. Peirce, The Writings of Charles S. Peirce: A Chronological Edition-Volume 2: 1867-1871 (Bloomington: Indiana University Press, 1982), 49-58. With photographs, the status of the index is much debated, especially the ways it performs reference with and without the presence of an icon. For a defense of the realist account of photographic reference, see André Bazin, "The Ontology of the Photographic Image," in What Is Cinema? (Berkeley: University of California Press, 1967), volume 1, 9-17. For a pithy anti-realist argument, see Joel Snyder, "Picturing Vision," Critical Inquiry 6, no. 3 (Spring, 1980): 499-526. For an alternative position that extends photographic indexicality to include the photographic act itself, see David Green and Joanna Lowry, "From Presence to Performative: Rethinking Photographic Indexicality," in Where Is the Photograph?, ed. David Green (Maidstone: Photoworks; Brighton: Photoforum, 2003), 47-62.

16 John Berger, “Uses of Photography," in About Looking (New York: Vintage, 1980), 55. 
as a non-essentializing approach to the ways photographs actually perform, for which there are no clear models in language. To attend to the ontology of absence is, for example, to study the slippery and antipodean ways that photographs express a sense of time. In photography, the past that is incompletely renewable is not completely unrenewable. Appearances that are fully formed are also unfinished vanishings, and instantaneousness that is pressed into a de-instantized duration begs the question of how long a moment should last in the first place. There is no good word to describe this quality of time which is both lossy and retentive, neither simply then nor simply now, but dislocated from both, somehow durably impermanent, or permanent but shot through with intermittence. ${ }^{17}$ Likewise, in the ontology of absence, photographs offer us not stories but a sense of proximity to them, a way of evoking stories without quite imparting them..$^{18}$ If in the ontology of presence, what is important are qualities of clarity, distinctness, specificity, and enduringness, the ontology of absence sees the reverse: the photograph first as a site of irresolution, occlusion, withdrawal, indistinctness, fragmentation, non-transmission, enigma-a site for the complications of time, space, narrative.

As I read them, Hayashi's works leverage both the ontologies of presence and absence. In her opticopiac collages, to look into what remains is to look into what generates what remains no longer, and to remember is to dispute memory's shape and status. The earth of the camps now both is and is not the earth of the camps then, and knowledge of their history is also incomprehension at all it signifies and was in experience. But it is a fertile, procreative incomprehension that preoccupies her. Her spatially fragmented and temporally asynchronous visions form a rare variety of testimony: dislodged from pronouncement and revelation in favour of a thick evidentiary malappearance,

17 See Peter Osborne, "Photography in an Expanding Field: Distributive Unity and Dominant Form," in Where Is the Photograph?, ed. David Green (Maidstone: Photoworks; Brighton: Photoforum, 2003), 63-70. Osborne writes: "The temporality of the photographic image is always that of a relation between a (constantly shifting) 'now' and the photograph's 'then'-a relation sustained, as if atemporal, by the material continuity of the photograph" (70). For a related and illuminating discussion on intermittence in the philosophy in cinema, see Nathaniel Dorsky, Devotional Cinema (Berkeley: Tuumba Press, 2003), 31-32.

18 The stories that photographs "tell" end up being the stories told about or from photographs. It is for this reason that photographs support true stories as much as false ones, knowledge as readily as the illusion of knowledge, hard conclusions no less than soft ones, open-ended and closed-ended readings alike. Even photographs with the strongest sense of informational presence generally show us effects without causes and causes without effects, and convey character, setting, plot, and theme - the basic elements of stories—in highly truncated forms. 
and so an awareness of ruptured American ideals and real, unrecuperated suffering. She induces an imagination of a history paradoxically built of brokenness, by turns rapt and volatile unto itself. Her pictures $d o$ endow the past with a continued sense of presence, but a presence of which we are not the master, and before which we remain in a state of tribulation. As much as anything, her pictures seem to be puzzles even their maker cannot solve.

Masumi Hayashi's life was bracketed by violence-by the circumstances of the prison camp where she was born, and her murder almost sixty-one years later. From the relative peace she enjoyed during her working life, she found path-breaking ways into the visualization of history. She found ways to conjure historical rupture in the terms of rupture itself - to create images seemingly in states of continuous emergence, dislocating themselves from established modes of communicating space and time. With a deep understanding of photography's predicating paradoxes, she crafted her visions around severances and intervals, in which each part is suspended in a hypertrophic, unwell whole. ${ }^{19}$ Her collages are too enervated to settle quietly into views, and too hungry to describe a single experience of seeing. Rather they point to something else, which might be described variously as the distance between the image and the world, the latencies and dormancies within self-knowledge and historical knowledge, and the never-conclusive act of facing traumatic history. If from one side Hayashi's approach is insistently iconoclastic, intent on breaking the monadic quality of photographic presence and converting "one" into "many," from another side her approach is insistently consolidative, intent on reconciling the aesthetic and the ethical. ${ }^{20}$ Hayashi's panochronoramic art of the camps is, in short, equally forthright and recondite. Like the tower at Manzanar made to console the dead and the living, Hayashi made her works as mediations. They arbitrate between presence and absence, hope and melancholy, the past as it stands to be known and the past as it refuses to be captured - and, not least, the real as it escapes into images while remaining hidden in time, strewn across the sites of our remembering.

\footnotetext{
19 My formulation here partly follows Jacques Rancière, who writes that the artist's task is to "dream of an art that would transmit meanings in the form of a rupture, with the very logic of meaningful situations." Jacques Rancière, The Politics of Aesthetics: The Distribution of the Sensible, trans. Gabriel Rockhill (London: Continuum, 2004), 63.

Peter Mendelsund, What We See When We Read (New York: Vintage, 2014), 388.
} 


\section{Jason Francisco}

is an acclaimed photographer and writer, and the author of numerous photoworks, essays, hybrid writings, artist's books and exhibitions on the complications of historical memory. His books include Far from Zion: Jews, Diaspora, Memory (Stanford University Press, 2006), The Steerage and Alfred Stieglitz, co-authored with Anne McCauley (University of California Press, 2012), An Unfinished Memory (Galicia Jewish Museum, Kraków, 2014), and Alive and Destroyed: A Document of the Holocaust in Time (Fall Line Press, forthcoming). At Emory University, Francisco is Associate Professor in photography studies in the Film and Media Studies department.

\section{References}

Alinder, Jasmine. Moving Images: Photography and the Japanese American Incarceration. Urbana and Chicago: University of Illinois Press, 2009.

Bazin, André. What Is Cinema? Volume 1. Berkeley: University of California Press, 1967. Benjamin, Walter. "Little History of Photography." In Walter Benjamin: Selected Writings, Volume 2, Part 2, 1931-1934, edited by Michael W. Jennings, Howard Eiland, and Gary Smith, 508-530. Translated by Rodney Livingstone. Cambridge, MA: Belknap Press, 2005.

Berger, John. About Looking. New York: Vintage, 1980.

Dorsky, Nathaniel. Devotional Cinema. Berkeley: Tuumba Press, 2003.

Green, David, and Joanna Lowry. "From Presence to Performative: Rethinking Photographic Indexicality." In Where Is the Photograph?, edited by David Green, 47-62. Maidstone: Photoworks; Brighton: Photoforum, 2003.

Griffin, Tim, et al. "Global Tendencies: Globalism and the Large-Scale Exhibition." Artforum 42, no. 3 (November 2003): 152-163.

Krauss, Rosalind. "Grids." October 9 (Summer 1979): 50-64.

Mendelsund, Peter. What We See When We Read. New York: Vintage, 2014.

Osborne, Peter. "Photography in an Expanding Field: Distributive Unity and Dominant Form." In Where Is the Photograph?, edited by David Green, $63-70$. Maidstone: Photoworks; Brighton: Photoforum, 2003.

Peirce, Charles S. The Writings of Charles S. Peirce: A Chronological Edition-Volume 2: 1867-1871. Bloomington: Indiana University Press, 1982.

Rancière, Jacques. The Politics of Aesthetics: The Distribution of the Sensible. Translated by Gabriel Rockhill. London: Continuum, 2004.

Snyder, Joel. “Picturing Vision." Critical Inquiry 6, no. 3 (Spring 1980): 499-526. 